\title{
MUSHROOM DRYING CHARACTERISTICS AND CHANGES OF COLOUR
}

\author{
Pavel Kic \\ Czech University of Life Sciences Prague, Czech Republic \\ kic@tf.czu.cz
}

\begin{abstract}
The aim of this paper is to present the results of research focused on the drying samples of wild and commercially used mushrooms and detect changes in their colours. Three types of mushrooms - Oyster mushroom (Pleurotus ostreatus), Portobello mushroom (Agaricus bisporus) and Red cracking bolete (Xerocomellus chrysenteron) have been investigated. The drying process was determined gravimetrically at normal summer temperature about $28.7^{\circ} \mathrm{C}$ and relative humidity of $43 \%$. The effect of increased convection at the flow velocity of $1.2 \mathrm{~m} \cdot \mathrm{s}^{-1}$ was measured on the drying process. The control sample was dried at a flow velocity of $0 \mathrm{~m} \cdot \mathrm{s}^{-1}$. The forced convection drying in comparison with natural convection samples reduced the time of drying considerably. The dry matter content was measured gravimetrically after drying in a hot air dryer at $105^{\circ} \mathrm{C}$. Since many consumers buy a mixture of dried mushrooms and they pay attention to the colour of the mushrooms, the effect of drying on the changes of the colour of the dried mushrooms was also observed. The biggest darkening occurs during the drying process of Agaricus bisporus. The measurement results form a good basis for further research in this field.
\end{abstract}

Keywords: forced drying, natural drying, moisture, spectrophotometer.

\section{Introduction}

The wild forest mushrooms and also mushrooms cultivated by artificial intensive methods is delicious food with nutritional value. Currently mushrooms are available in shops during the whole year. But there are some reasons for conservation and processing. The oldest and often also the most popular way to process mushrooms is drying. It is generally known that, for example, a true good potato soup is not well cooked without dried mushrooms. Fresh or frozen will not give to this soup the right smell and taste. The advantage is that almost all kinds of mushrooms can be conserved by drying. However, some principles should be respected.

Mushrooms are extremely perishable and several physiological and morphological changes occur after harvest, which make these mushrooms unacceptable for consumption [1]. Drying characteristics of Oyster mushrooms (Pleurotus ostreatus) under sun-drying and tunnel drying were studied at laboratory level. Colour, water activity, moisture content and rehydration ratio were used as the criteria for evaluating the product quality. Dehydrated mushroom of desirable quality in terms of colour, water activity, and rehydration ratio characteristics could be obtained.

Practical recommendations that should be respected can be found, e.g., in [2]. Mushrooms must not ever get soggy or mouldy. Mushrooms must be stored in a cool place and with sufficient ventilation. Otherwise, there is a risk of their degradation. That is when protein breakdown occurs and so disturbed proteins can cause gastrointestinal problems similar to those of eating spoiled meat. Drying mushrooms in the sun is not recommended - it will almost certainly spoil the mushrooms. It is recommended to dry them in shade and draught, preferably on wooden frames covered with polyethylene mesh. Drying in this way usually takes several days.

The mushrooms can be dried also on the threads. There should be knots between the slices. Thanks to them, the mushrooms will not move and dry quickly. It should be put into a space with air draught. Another option is drying in the oven. Slices of mushrooms are spread on a baking sheet lined with baking paper, starting at $45^{\circ} \mathrm{C}$ and raising the temperature to a maximum of $75^{\circ} \mathrm{C}$ at the end. Drying is required for about 4 to 5 hours. Ideal is to turn on the hot air and let the fan go on. Properly dried mushrooms are known to be brittle and easy to break.

The mushrooms suitable for further processing should be especially healthy, non-spicy, solid and free of mould. Although fresh mushrooms can contain up to $95 \%$ of water, drying to reduce the water content to $5 \%$ is excellent. Drying sieves are available for drying outdoors and in the apartment. Drying of mushrooms in the tumble dryer is quick, and the fungi are not moulded during drying. It is also possible drying them in the oven, but it is necessary to control the temperature, which should not exceed $40{ }^{\circ} \mathrm{C}$. Ideal is an oven with a fan [3]. 
Wormy mushrooms are strongly not recommended from a hygienic point of view. Worms infiltrate microorganisms into the interior of the organisms, which rapidly increase and cause faster fungus destruction (rotting and moulding). In good storage, dried mushrooms can be used even more seasons, but they should be consumed within three years. They should be stored in completely dry conditions, for example, in a well-sealed glass. Drying mushrooms in the sun is not recommended - it will almost certainly spoil the mushrooms. It is recommended drying them in shade and draught, preferably on wooden frames covered with polyethylene mesh [4].

These traditional methods of mushroom drying have been known for many generations, but the theoretical foundations that are usable in modern food production are not well known. That is why, in recent years, the attention has also been paid to the research of this issue. E.g., temperature influence on the process of drying and mathematical modelling of the drying process, effective moisture diffusivity and activation energy calculations are presented in [5]. The article [6] provides results of an experimental investigation of three hybrid drying technologies on the drying characteristics and key quality parameters of shiitake mushroom (Lentinus edodes). The drying techniques tested at the laboratory scale are mid-infrared-assisted convection drying, hot air coupled with radio frequency drying, and hot air coupled with microwave drying.

Extreme treatments were used to create mushroom samples with clear differences in the dry matter content in the research [7]. The accessibility of water in the casing was influenced by changing the thickness and osmolarity of the casing layer. This resulted in dry matter contents in mushrooms between 7 and $14 \%$. All samples were examined for quality characteristics like colour, firmness and shelf-life. The colour and mass transfer kinetics during air drying as well desorption isotherms at 40 , 50 , and $60^{\circ} \mathrm{C}$ of Pleurotus ostreatus mushrooms were studied in [8]. Colour analysis was based on reduced lightness change with time, temperature and pre-treatment. Button mushrooms in the form of whole and slices were dried using convective hot air drying and microwave drying methods in the research [9]. The decrease in brightness (indicated by L-value) in the dried samples was about $44 \%$ as compared to the fresh ones.

The attention to different material drying under artificial conditions is paid in different scientific publications, e.g. $[10 ; 11]$. The aim of this work is to bring some new experimental and theoretical investigations focused on drying selected samples of wild and also commercially grown mushrooms and detect changes in their colours.

\section{Materials and methods}

The laboratory measurements were carried out at the Faculty of Engineering CULS Prague during summer weather conditions in July and August. The technical equipment used for the experiments was a forced convection system of own design [10;11].

Two types of mushrooms growing in the wild and also grown commercially and commonly available in shops, such as Oyster mushroom (Pleurotus ostreatus) (samples M1 and M4), Portobello mushroom (Agaricus bisporus) (samples M2 and M5) have been investigated. The Red cracking bolete (Xerocomellus chrysenteron) (samples M3 and M6) was chosen from the wild mushrooms in the forests of the central zone.

These three types of mushroom have been selected for this research because they differ markedly by their structure, the conditions of the substrate on which they grow, and the verified results of the drying process. There are many phylum, classes, orders, families, genus and mushroom species, which in some cases differ greatly or have similar features. Selected mushrooms are certain representatives in this area, as they are well known to the public and they are readily available.

There were installed in each of three drying chambers a thin layer of slices cut mushroom on a sieve tray with mesh $3 \times 4 \mathrm{~mm}$ of the total area approximately $20,400 \mathrm{~mm}^{2}$. A space, in which the perforated trays with samples were placed, allows independent measurements during drying at different flow rates of the drying air. The airflow delivered by the fan of $120 \mathrm{~mm}$ diameter is controlled by fan revolutions. The forced drying was with the air velocity in the drying chambers $1.2 \mathrm{~m} \cdot \mathrm{s}^{-1}$ and the control measurement was with natural convection drying by the same temperature, but with $0 \mathrm{~m} \cdot \mathrm{s}^{-1}$ air velocity. 
Air speed, air temperature and humidity, moisture content and dry matter were measured by instruments and sensors according to the methodology in $[10 ; 11]$. Each measuring tray was weighed during the first 5 hours every $30 \mathrm{~min}$, later during the next period every $60 \mathrm{~min}$. The total drying time 25 hours was adapted to the need for a determination of the lowest moisture content, which can be achieved by convective drying. The following main parameters of the drying process are calculated from the measured values: water content $\mathrm{u}$, moisture $\mathrm{w}_{\mathrm{k}}$ and the drying rate $\mathrm{N}$ according to the literature $[10 ; 11]$.

The colour attributes $\mathrm{L}^{*}$ value (lightness), redness ( $\mathrm{a}$ *values) and yellowness ( $\mathrm{b}^{*}$ values) were measured of each fresh sample, after convection (natural or forced) drying and after hot air drying in $105^{\circ} \mathrm{C}$. The lightness, $\mathrm{L}^{*}$, represents the darkest black at $\mathrm{L}^{*}=0$, and the brightest white at $\mathrm{L}^{*}=100$. These values are presented as dimensionless. The instrument used for this research was the Spectrophotometer CM-600d Konica Minolta.

\section{Results and discussion}

The kinetics of the mushroom drying process caused by forced and natural convection with the air velocities $\left(1.2 \mathrm{~m} \cdot \mathrm{s}^{-1}\right.$ and $\left.0 \mathrm{~m} \cdot \mathrm{s}^{-1}\right)$ is described by the curves in Fig. 1-4. The whole convection drying time $1,500 \mathrm{~min}$ ( 25 hours) was sufficient to the maximal drop of the water content, which can be achieved by convection of the air temperature $28.7^{\circ} \mathrm{C}$ and relative humidity $43 \%$.

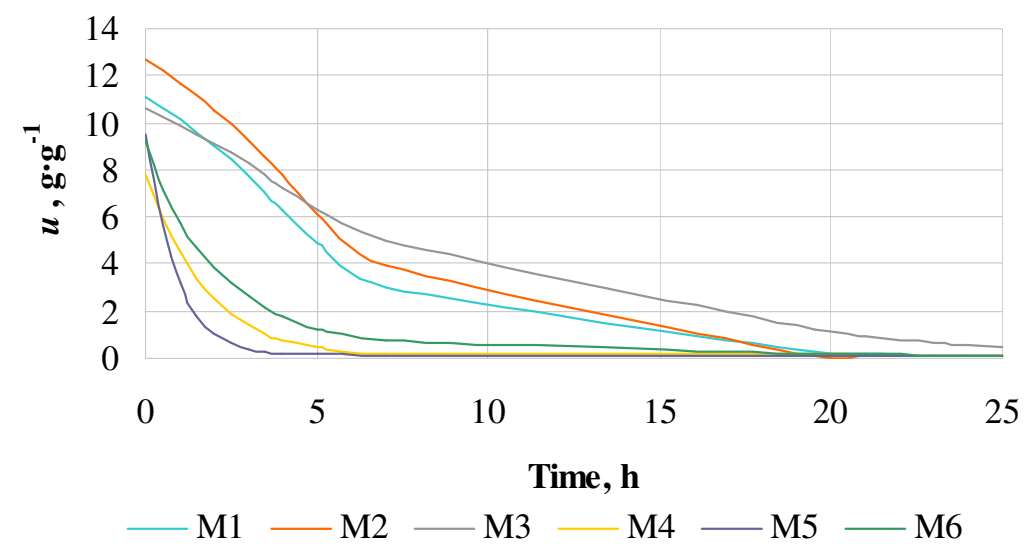

Fig. 1. Water content $u$ of all 6 mushroom samples during $25 \mathrm{~h}$ of convection drying with air velocities $0 \mathrm{~m} \cdot \mathrm{s}^{-1}(\mathrm{M1}, \mathrm{M} 2, \mathrm{M3})$ and $1.2 \mathrm{~m} \cdot \mathrm{s}^{-1}(\mathrm{M} 4, \mathrm{M} 5$, M6)

Fig. 1 shows that in the case of all mushroom samples (M4, M5, M6) the forced convection drying $\left(v=1.2 \mathrm{~m} \cdot \mathrm{s}^{-1}\right)$ in comparison with natural convection $\left(v=0 \mathrm{~m} \cdot \mathrm{s}^{-1}\right)$ samples $(\mathrm{M} 1, \mathrm{M} 2, \mathrm{M} 3)$ reduced the time of drying considerably. The water content of Red cracking bolete (Xerocomellus chrysenteron) samples M3 and M6 declined most slowly.

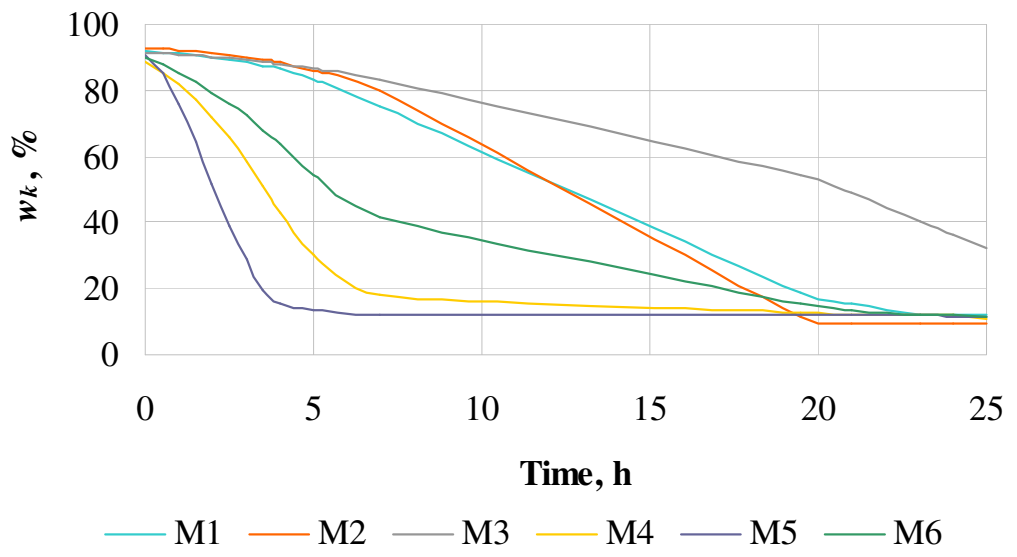

Fig. 2. Moisture $w_{k}$ of all 6 mushroom samples during $25 \mathrm{~h}$ of convection drying with air velocities $0 \mathrm{~m} \cdot \mathrm{s}^{-1}(\mathrm{M} 1, \mathrm{M} 2, \mathrm{M3})$ and $1.2 \mathrm{~m} \cdot \mathrm{s}^{-1}(\mathrm{M} 4, \mathrm{M} 5, \mathrm{M6})$ 
The course of moisture $\mathrm{w}_{\mathrm{k}}$ during the $25 \mathrm{~h}$ of convection drying is presented in Fig. 2. The decrease of moisture of all mushroom samples is significantly slower in the case of natural convection $\left(v=0 \mathrm{~m} \cdot \mathrm{s}^{-1}\right)$ samples (M1, M2, M3) than with forced convection (M4, M5, M6) with the air velocity $1.2 \mathrm{~m} \cdot \mathrm{s}^{-1}$. The moisture of Red cracking bolete (Xerocomellus chrysenteron) samples M3 and M6 declined most slowly.

The course of the drying rate $\mathrm{N}$ during 25 hours of convection drying is presented in Fig. 3. Very high drying rate of all 3 mushroom samples in forced convection is during the first 3 minutes. The highest drying rate was achieved by the sample M5 (Portobello mushroom, Agaricus bisporus). According to Fig. 3 the difference between the drying rate with the air velocity $1.2 \mathrm{~m} \cdot \mathrm{s}^{-1}$ of the samples M5 and M6 is rather small. It is obvious that the drying rate with natural convection (M1, M2 and M3) is very low in all samples in comparison with forced convection.

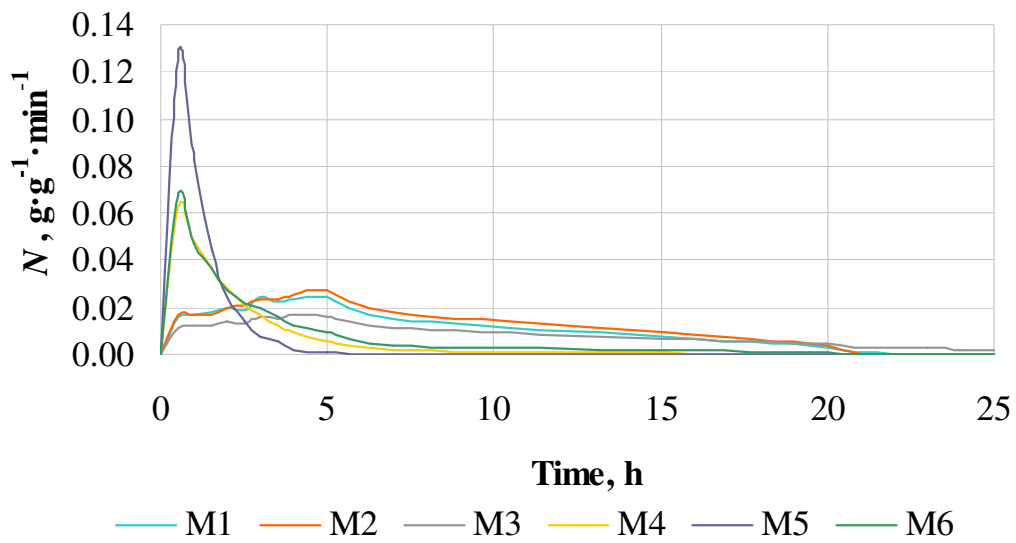

Fig. 3. Drying rate $\mathbf{N}$ of all 6 mushroom samples during $25 \mathrm{~h}$ of convection drying with air velocities $0 \mathrm{~m} \cdot \mathrm{s}^{-1}(\mathrm{M} 1, \mathrm{M} 2, \mathrm{M3})$ and $1.2 \mathrm{~m} \cdot \mathrm{s}^{-1}(\mathrm{M} 4, \mathrm{M} 5$, M6)

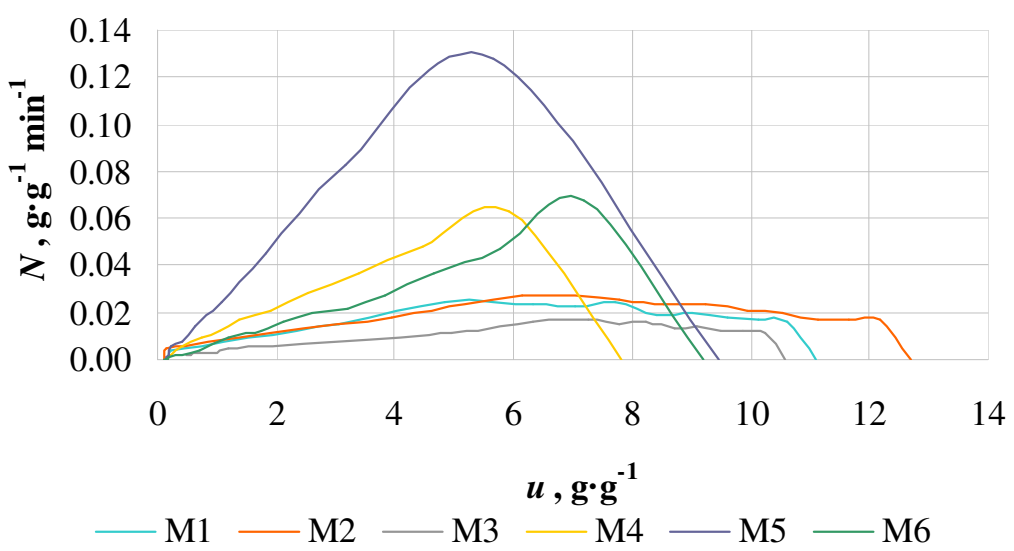

Fig. 4. Drying rate $\mathbf{N}$ of all 6 mushroom samples during $25 \mathrm{~h}$ of convection drying with air velocities $0 \mathrm{~m} \cdot \mathrm{s}^{-1}(\mathrm{M} 1, \mathrm{M} 2, \mathrm{M3})$ and $1.2 \mathrm{~m} \cdot \mathrm{s}^{-1}(\mathrm{M} 4, \mathrm{M} 5$, M6) as function of water content $u$

Rather interesting is the dependence of the drying rate on the water content presented in Fig. 4, describing both very important parameters of the drying process. The best relation between the drying rate and the water content is achieved in forced drying of M5 (Portobello mushroom, Agaricus bisporus).

The mean values and standard deviations (SD) calculated from the results of measurements of the lightness $\mathrm{L}^{*}$ are presented in Table 1 . There are also the colour specification $\mathrm{a}^{*}$ and $\mathrm{b}^{*}$ mean values with SD included in Table 1.

The results of the lightness $\mathrm{L}^{*}$ indicate that the lightest mushrooms are Portobello mushroom (Agaricus bisporus), but the biggest darkening occurs during the natural drying process. Forced drying showed less darkness than natural convection drying. Changes in colour shades, $\mathrm{a}^{*}$ and $\mathrm{b}^{*}$, however, were not so significant in this mushroom. The changes of colour are obvious in Fig. 5 and 6. 
Table 1

Colour range coordinates $\left(\mathrm{L}^{*}, \mathrm{a}^{*}\right.$ and $\mathrm{b}^{*}$ mean values with SD) of fresh mushroom, mushroom after either natural or forced convection drying and after drying in oven by hot air $105^{\circ} \mathrm{C}$

\begin{tabular}{|c|c|c|c|c|}
\hline Material & Conditions & $\mathrm{L}^{*} \pm \mathrm{SD}$ & $a^{*} \pm S D$ & $b^{*} \pm S D$ \\
\hline \multirow{3}{*}{$\begin{array}{l}\text { Red cracking bol. } \\
\text { Xerocomellus } \\
\text { chrysenteron (M1) }\end{array}$} & Fresh & $59.94 \pm 2.60$ & $-0.45 \pm 1.40$ & $23.60 \pm 4.80$ \\
\hline & Natural drying & $54.29 \pm 2.96$ & $5.51 \pm 1.29$ & $21.44 \pm 6.21$ \\
\hline & Hot air $105^{\circ} \mathrm{C}$ & $48.84 \pm 4.02$ & $8.42 \pm 0.49$ & $26.10 \pm 2.36$ \\
\hline \multirow{3}{*}{$\begin{array}{l}\text { Red cracking bol. } \\
\text { Xerocomellus } \\
\text { chrysenteron (M4) }\end{array}$} & Fresh & $61.35 \pm 13.58$ & $-0.3 \pm 1.14$ & $19.42 \pm 2.56$ \\
\hline & Forced drying & $53.86 \pm 10.08$ & $4.59 \pm 2.38$ & $20.97 \pm 2.04$ \\
\hline & Hot air $105^{\circ} \mathrm{C}$ & $43.01 \pm 6.92$ & $5.81 \pm 1.23$ & $15.26 \pm 4.96$ \\
\hline \multirow{3}{*}{$\begin{array}{l}\text { Oyster mushroom } \\
\text { Pleurotus ostreatus } \\
\text { (M2) }\end{array}$} & Fresh & $75.94 \pm 2.71$ & $-0.21 \pm 0.52$ & $12.29 \pm 1.41$ \\
\hline & Natural drying & $80.18 \pm 8.09$ & $-0.57 \pm 0.92$ & $28.37 \pm 1.69$ \\
\hline & Hot air $105^{\circ} \mathrm{C}$ & $74.34 \pm 4.09$ & $3.19 \pm 0.68$ & $26.66 \pm 0.95$ \\
\hline \multirow{3}{*}{$\begin{array}{l}\text { Oyster mushroom } \\
\text { Pleurotus ostreatus } \\
\text { (M5) }\end{array}$} & Fresh & $78.09 \pm 6.64$ & $-0.04 \pm 1.09$ & $13.05 \pm 3.82$ \\
\hline & Forced drying & $77.15 \pm 7.85$ & $-0.41 \pm 1.29$ & $27.60 \pm 1.49$ \\
\hline & Hot air $105^{\circ} \mathrm{C}$ & $68.98 \pm 5.05$ & $6.17 \pm 1.49$ & $29.80 \pm 2.86$ \\
\hline \multirow{3}{*}{$\begin{array}{l}\text { Portobello mush. } \\
\text { Agaricus bisporus } \\
\text { (M3) }\end{array}$} & Fresh & $83.63 \pm 7.07$ & $1.81 \pm 1.39$ & $12.77 \pm 1.39$ \\
\hline & Natural drying & $71.35 \pm 1.71$ & $3.84 \pm 0.75$ & $19.97 \pm 1.28$ \\
\hline & Hot air $105^{\circ} \mathrm{C}$ & $53.63 \pm 5.64$ & $8.17 \pm 0.68$ & $25.40 \pm 2.93$ \\
\hline \multirow{3}{*}{$\begin{array}{l}\text { Portobello mush. } \\
\text { Agaricus bisporus } \\
\text { (M6) }\end{array}$} & Fresh & $83.39 \pm 4.68$ & $2.88 \pm 1.77$ & $15.17 \pm 1.60$ \\
\hline & Forced drying & $73.24 \pm 3.43$ & $3.45 \pm 1.60$ & $18.00 \pm 0.38$ \\
\hline & Hot air $105^{\circ} \mathrm{C}$ & $55.60 \pm 11.99$ & $6.80 \pm 0.97$ & $21.98 \pm 4.39$ \\
\hline
\end{tabular}

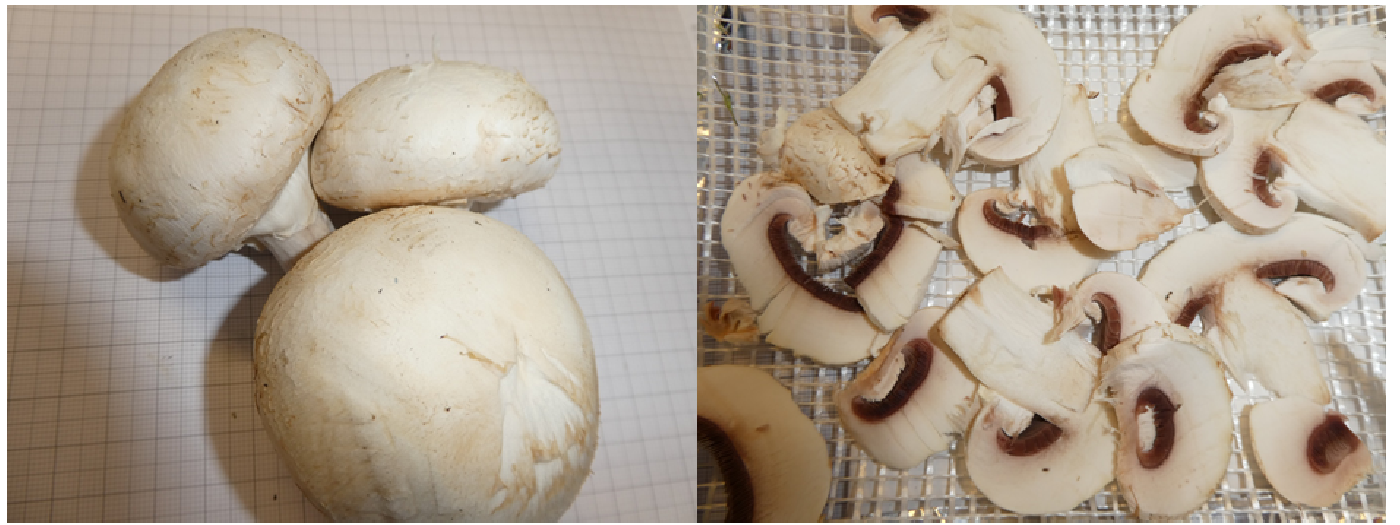

Fig. 5. Examples of fresh Portobello mushroom (Agaricus bisporus) before (left) and after cutting and inserting into convection drying bowls (right)

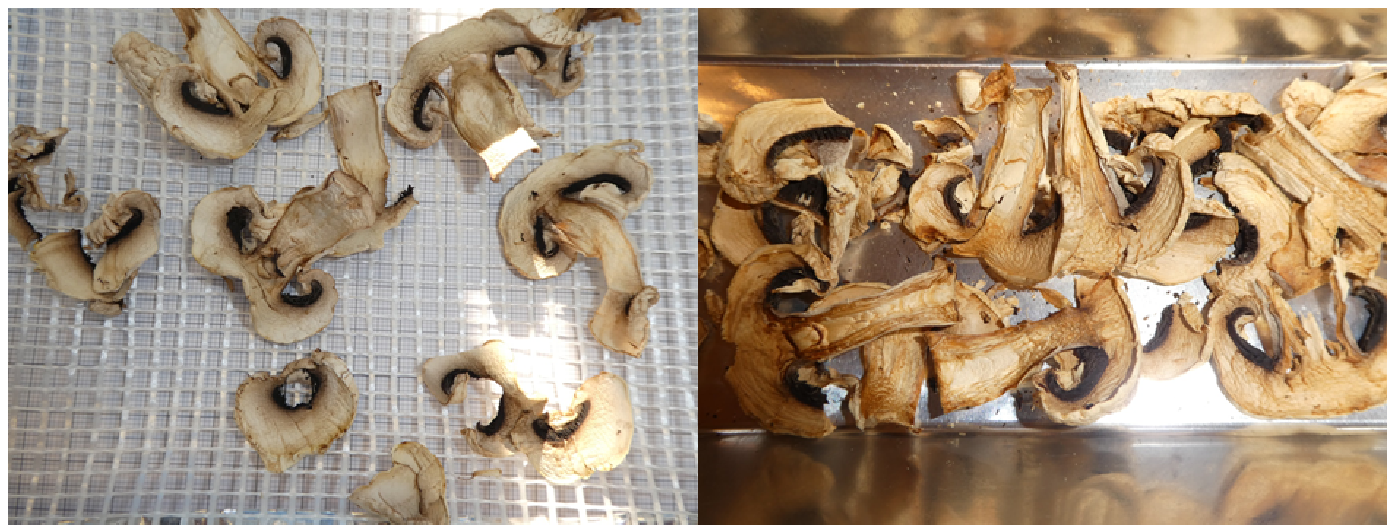

Fig. 6. Examples of Portobello mushroom (Agaricus bisporus) after convection drying (left) and after hot air drying $105^{\circ} \mathrm{C}$ (right) 
More obvious influence of drying showed a change in colour a* in the darkest mushroom, which is Red cracking bolete (Xerocomellus chrysenteron). The original green shade has changed both in natural and forced drying by shifting to red. The Oyster mushroom (Pleurotus ostreatus) did not change much in terms of shade by convection drying. However, changes were much more obvious due to drying in a hot-air oven at $105^{\circ} \mathrm{C}$.

\section{Conclusions}

1. This research has been useful for verification of the influence of different air velocities on the drying process of several typical types of common mushrooms.

2. It has been found that the forced convection has a strong and positive influence on the drying time in comparison with free drying by natural convection. The forced convection drying $\left(v=1.2 \mathrm{~m} \cdot \mathrm{s}^{-1}\right)$ in comparison with natural convection $\left(v=0 \mathrm{~m} \cdot \mathrm{s}^{-1}\right)$ samples reduced the time of drying considerably (approximately four times). In order to achieve the suitable moisture the optimization of drying time should be provided and respected.

3. Future research in this area should be focused on the study of other factors influencing the drying process, especially in different air temperatures, partly described and expressed by the drying coefficient.

4. The commercial growing and drying of mushrooms is influenced by the market factors, nevertheless it can be recommended mainly for drying of Portobello mushroom (Agaricus bisporus). Drying of Red cracking bolete (Xerocomellus chrysenteron) is not recommendable.

5. Changes of colour is an important parameter, which should be studied also for other types of mushrooms, mainly for the mushrooms used for commercial purposes.

\section{References}

[1] Martinez-Soto G., Torres-Reyes E., Bautista-Justo M. Drying of Pleurotus ostreatus mushrooms by sun drying and tunnel drying. Proceedings of the second inter-american drying conference "2nd Inter-American Drying Conference (IADC)", July 8-10, 2001, Boca del Rio, Mexico, pp. 299-305.

[2] Jak správně sušit a uchovat houby? Zkuste nit, síto nebo pečicí papír. (How to properly dry and preserve mushrooms? Try a thread, a sieve or a baking paper). [online] [19.04.2018]. Available at: http://recepty.blesk.cz/clanek/vareni/3038/jak-spravne-susit-a-uchovat-houby-zkuste-nit-sitonebo-pecici-papir.html?utm_source=recepty.blesk.cz\&utm_medium=copy. (In Czech)

[3] Sbíráte houby? I jejich zpracování má svá pravidla! (Do you collect mushrooms? Even their processing has its own rules!). (In Czech) [online] [19.04.2018]. Available at: https://www.prozeny.cz/clanek/sbirate-houby-i-jejich-zpracovani-ma-sva-pravidla-2468.

[4] Sušení hub (Drying mushrooms). (In Czech) [online] [19.04.2018]. Available at: https://ona.idnes.cz/dvanact-rad-pro-opatrne-houbare-d3o /recepty.aspx?c=A070730_153312_recepty_ves.

[5] Mihalcea L.I., Bucur F.C., Cantaragiu A.M.M. Gurgu L.C. Borda D.D. Iordachescu G.S. Temperature influence on the agaricus bisporus mushrooms dehydration process. Scientific study and research-chemistry and chemical engineering biotechnology food industry, vol. 17, 2016, pp. 323-333.

[6] Wang H., Zhang M., Mujumdar A.S. Comparison of Three New Drying Methods for Drying Characteristics and Quality of Shiitake Mushroom (Lentinus edodes). Drying Technology, vol. 32, 2014, 1791-1802.

[7] Van Loon P.C.C., Swinkels H.A.T.I., Van Griensven L.J.L.D. Dry matter content in mushrooms (Agaricus bisporus) as an indicator for mushroom quality. Proceeding of 15th International Congress on the "Science and Cultivation of Edible Fungi", May 15-19, 2000, Maastricht, Netherlands, pp. 507-513.

[8] Xanthopoulos G., Boudouvis A.G., Aravantinos-Karlatos E. Color and Mass Transfer Kinetics During Air Drying of Pretreated Oyster Mushrooms (Pleurotus ostreatus spp.). Drying Technology, vol. 32, 2014, pp.77-88. 
[9] Mittal T.C., Sharma S.R., Muker J.S., Gupta S.K. Drying behaviour and change in colour and textural properties of mushroom during drying. International journal of food engineering, vol. 8, 2012, pp. 1-11.

[10] Kic P., Aboltins A. Convective drying of poultry manure by different air speeds. Proceedings of International Scientific Conference "Engineering for Rural Development". 2013., Jelgava, Latvia University of Agriculture, Latvia, pp. 121-125.

[11] Aboltins A., Kic P. Research of some medical plants drying process. Proceedings of International Scientific Conference "Engineering for Rural Development". 2016, Jelgava, Latvia University of Agriculture, Latvia, pp. 1145-1150. 